INDEPENDENT JOURNAL OF MANAGEMENT \& PRODUCTION (IJM\&P) http://www.ijmp.jor.br

V. 11, n. 7, November - December 2020 ISSN: 2236-269X

DOI: 10.14807/ijmp.v11i7.1231

\title{
A GROUNDED THEORY EXPLORATION OF APPRAISAL PROCESS OF CAPITAL INVESTMENT DECISIONS - CAPEX APPRAISAL MODEL (CAM)
}

\author{
Umair Baig \\ Benazir Bhutto Shaheed University, Layri Karachi \\ E-mail: umaiirbaig@gmail.com \\ Manzoor Anwar Khalidi \\ Barrett Hodgeon University, Pakistan \\ E-mail: makhalidi@gmail.com
}

Submission: $12 / 30 / 2019$

Revision: 2/10/2020

Accept: 2/22/2020

\section{ABSTRACT}

The purpose of this study was to explore the appraisal process of capital investment decisions. The study adopted the constructivist grounded theory for exploring and develop a theory on appraisal process of capital investment decision. Theoretical sampling was used for this purpose and 48 in-depth interviews were conducted from finance executives of listed companies of Pakistan Stock Exchange. After transcription of all of the interviews, NVIVO software was used for analysis. Initially, 38 concepts and 19 categories were obtained from the initial coding of 48 cases. In the next stage, using focused coding, 19 initial categories were classified into 09 categories. These 09 categories represent each stage of the appraisal process of capital investment Decision. These stages are Idea generation, Strategic planning, Analysis, Risk Evaluation, Selection, Mode of finance, Implementation, Monitoring and control, and Post-audit. The development of appraisal process stages is the novelty of this study and key theoretical contribution. Findings provide an indepth understanding of the systematic way that industry appraises capital investments. This study opens grounds for new knowledge for academia, adds to relevant literature and reduces the gap between the corporate world and academia.

Keywords: Capex Appraisal Model (CAM); Capital Budgeting; Constructivist grounded theory; Capex Analysis; Capital investment decision 
DOI: 10.14807/ijmp.v11i7.1231

\section{INTRODUCTION}

Capital investment can be defined as making a huge outflow of cash now in the hopes of gaining subsequent cash inflows in the future. The terms "capital investment”, “capital expenditures”, “projects”, and “capital budgeting” are synonyms that are used for long term investment (CHANDRA, 2014). All decisions that are related to the choice of available investment opportunities that provide economic benefit for more than a year are considered as the capital investment decisions (PETROVIĆ, 2013). According to Ehrhardt (2016), capital investment must be rational and always executed in the present with the objective of getting rewards from an upcoming uncertain future. Horne (2013) stated that capital investment decisions are perhaps the most important decisions for the corporates as far as value creation is concerned, the others being financing and dividend policy decisions.

Capital investment appraisal process help the finance managers to make crucial decisions regarding the scarce resources of the firm regarding the amount to invest, and the project to invest. (BALDENIUS, 2003; BASU; DREW 2010; DOUMPOS; ZOPOUNIDIS, 2014; VERBEETEN, 2006). Capital investment decisions involve long term commitment for a firm's scarce resources and they are vital for long term success of a firm. The reason being, the profitability of a firm is a direct consequence of the capital investment decisions that are taken today.

Some projects are routine and do not affect the company's strategic direction and financial policies, or change the course of action as planned by the top management, however, other capital investment decisions have a strategic value in the sense that they impact the company's future market and financial position allowing it to grow in terms of products and services, and enter new markets and generate revenues from resources and operations other than the existing core products or markets of the company.

The commitment of funds to a particular project can thus be enormous and irreversible; ill-judged or inadequate capital investment decisions even for the large and financially sound corporations of today can lead to issues of bankruptcy and insolvency in the future. It is, therefore, the obligation of the decision-makers to make to carry out a strategic and prudent review of the long-term capital investment opportunities through a diligent and thorough decision-making process (ANDREWS; BUTLER, 1986).

According to Eljelly and Abuidris (2001), companies require a process of on-going capital investment, in order to live through the turbulence of rapidly changing environment of the global market place. Similarly, A firm is likely to encounter liquidity problems, that may 
DOI: 10.14807/ijmp.v11i7.1231

culminate into financial distress if such long-term investments turn out to be unsuccessful (ARGENTI, 1977; KEASEY; WATSON, 1989). Holmes (1998), and Du and Pienaar (2005) therefore emphasize that long-term capital outlay is a matter of crucial concern for the top management because all concerned decisions related to capital expenditures or capital investment deem to have major impact on the future success of a company.

Mintzberg et al. (1976) have argued that the capital investment decision-making process usually fails when there exists a lack of understanding and awareness about the risk \& returns of long-term projects raising doubts on the capital budgeting process. Akalu (2001) and Remer and Nieto (1995) are of the view that while the capital investment appraisal process have been a topic of a significant number of empirical studies over the last three decades, these researches, however, are mainly concentrated on the capital investment techniques practised by companies, this includes spatial as well as temporal i.e practices across different countries as well as the changes across time, for example, researchers such as Klammer (1973), Pike (1988), Pike (1996) and Pike and Neale (2006) have all examined the changes in the practices of capital investment appraisal techniques with the passage of time.

The long-term capital investment decisions are based on meaningful capital utilisation, appropriate planning and adroit execution with strong control over the entire capital planning process (AKALU, 2003). The process is specifically influenced by the degree to which the strategies based or drawn on pertinent ideas have been applied rationally. According to McIntyre and Coulthurst (1985), the success of a capital investment process depends on a number of factors. This includes the utilisation of appropriate investment appraisal techniques within the capital budgeting process, perceiving the timing and availability of different investment opportunities, estimating the cashflow streams taking into consideration the future changes in environmental conditions within which the undertaking operates, and lastly, taking corrective actions regarding any investment plans, after reviewing the results.

\subsection{Research problem}

In the past five decades, a significant portion of research has been carried out across the globe, related to the investment appraisal processes in general and on investment appraisal techniques in particular. According to Remer and Nieto (1995) acknowledge a key concern is attributed to building up literature on practices of capital budgeting technique has been a topic of many empirical studies. However, these researches mainly concentrated on the selection phase of the capital budgeting. 
DOI: 10.14807/ijmp.v11i7.1231

In the broader sense, researchers have documented the practices of capital investment techniques amongst various companies from the perspectives of different countries. Burns et al. (2009) stated that it has been almost 30 years since a detailed literature review and survey on capital investment was done. Currently, future researchers are responsible to explore all the required stages for evaluating appraisal process of capital investment decisions.

Kengatharan (2016) stated that another prospect for future scholars is the study of the characteristics of the firm such as strategies, incentive and reward mechanism, financial structure, and distribution of decision rights, etc., that have been known to affect practices of capital budgeting. However, the pertinent question is to ask whether sophisticated capital budgeting practices are important to all types of investments. Moreover, explore the procedures to appraise capital investment in different sectors and industries. Thus, these conundrums need to be well investigated.

Thus, the above-mentioned problem is highlighted the major gaps in the existing literature and overlooked areas of capital investment decisions. Hence, the following research objective and question are below to fill the gap through newly developed theory in the context of capital investment decisions.

\subsection{Research objective and question}

Researchers such as Klammer and Walker (1984), Pike (1988), Pike (1996), Pike and Neale, (2009) and Burns et al. (2009) have all acknowledged that the appraisal process of capital investment decisions does matter for firm performance and this process keeps changing with the passage of time. Therefore, the future researcher responsible to explore the whole process of capital investment decision instead of the selection phase of capital budgeting.

There is a lack of properly documented research on appraisal process of capital investment decisions specifically in developing countries. Even the research that has already been conducted on the topic does not include qualitative factors. Hence, there is no such comprehensive theory developed earlier in developing countries in general and particularly in Pakistan. Therefore, this exploratory research on the appraisal process of capital investment decisions provides an accurate and broad picture of the appraisal process of capital investment decision in the corporate sector of Pakistan.

Since the practices keep changing with time and other factors, hence the main objective of the study is to developed theory regarding the appraisal process of capital investment in the 
DOI: 10.14807/ijmp.v11i7.1231

context of Pakistan. To get understating of the above-mentioned objective, this research study is based on one basic question:

Research Question: How does the corporations in Pakistan appraise the process of capital investments decision?

\section{LITERATURE REVIEW}

It has been almost 30 years since a detailed literature review and survey of the capital investment process was undertaken. It seemed as if the earlier scholars of finance deliberately left this task (to discover and work on the ignored areas of the capital investment process) for the upcoming researchers (BURNS, 2009; KENGATHARAN, 2016; PINCHES, 1982; MALENKO, 2019). The earlier comprehensive surveys were conducted by King (1975), Gitman and Forrester (1977), Scott and Petty (1984), McIntyre and Coulthurst (1985), Mukherjee (1987), Burns (2009), Maroyi et al., (2012), Correia, (2012), Andor et al., (2015), Kengatharan (2016), Batra and Verma (2017) and Malenko (2019).

The capital investment process, first initiated by King (1975) who used a six-stage analysis of the investment appraisal process, which included the stages of (1) Triggering (2) Screening (3) Analysis (4) Evaluation (5) Transmission (6) Decision. The later scholars such as Gitman and Forrester (1977), and Pinches (1982) used a 4-stage analysis consisting of (1) Identification (2) Development (3) Selection and (4) Control.

Scott and Petty (1984), and McIntyre and Coulthurst (1985) reduced it to a 3-stage process. Pike and Neale (2006) explored the process in the context of five stages (1) Determination of Budget (2) Search for development (3) Evaluation (4) Authorization (5) Monitoring and control. Arnold (2008) examined eight stage process (1) Generation of Idea (2) Development of proposal (3) Project Classification (4) Screening (5) Appraisal (6) Authorization (7) Implementation (8) Post completion audit.

Burns, (2009) had recommended four stages (1) Identification (2) Proposal Development (3) Selection of Project (4) Control. Chandra P. (2014) suggested six stages (1) Planning (2) Analysis (3) Selection (4) Financing (5) Implementation (6) Control. However, Burns (2009) highlighted that four stages are the most concise stages to know the process of capital investment. 1. Identification stage is the idea generation phase that is how the idea comes either up to down or down to upward direction and make practically possible. 2 . Development phase basically clarifies the project screening procedure, 3. Selection phase is mainly based upon quantitative analysis of capital investment process and this phase determines the possibility of acceptance or rejection of any investment and 4. Control phase 
DOI: 10.14807/ijmp.v11i7.1231

dealing with the performance appraisal and addressing any discrepancies found that need to be rectified in the future. All four phases apply to the appraisal of the capital investment process. And encompass the common areas of interest, which include personnel, procedures, and methods involved, along with the rationale for each.

The majority of researchers surveys primarily on the selection phase of capital budgeting, and while giving less attention to other phases of the capital investment process (GORDON; PINCHES, 1984). Even in modern studies, related to capital budgeting surveys are very much closed to the practices of capital budgeting techniques only or covering the selection phase of the appraisal process of capital budgeting. For example; (MAROYI et al., 2012; CORREIA, 2012; ANDOR et al., 2015; KENGATHARAN 2016; BATRA; VERMA, S. 2017; MALENKO, 2019). However, past studies are highlighting the same issue and emphasizing to conduct researches on the whole appraisal process of capital investment decisions, in this section, revealed past researcher exclusive research study to highlight the existing real problem in the context of appraisal process of capital investment decisions.

Scott and Petty (1984) undertook a synthesis of previous surveys of major American companies, they describe the capital investment process in terms of three phases (1) Definition of Project and estimation of cash flow (2) Analysis of finance and selection of project, and (3) Implementation and review of the Project. Gitman and Forrester (1977) mentioned that the definition of project and estimation cash flow is the most difficult aspect of the capital budgeting process. However, analysis of the finance and selection phase of evaluating the longterm investment process that receives the most attention in the literature.

There is the reason that huge research works are available in the area at the cost of insufficient research on the other phases of the capital investment appraisal process. There are several research questions relevant to each stage that need to be answered; for example, in phase 1, (Identification) future researchers need to explore the systems of reward, the structure of the firm, and procedural features that influence the identification of projects.

In phase 2, (Development/Screening) researchers need to examine corporate vs divisional biases, process and assumption behind the estimation of cash flows, strategic considerations during the screening process, elements of the data, risk assessment, possibility of cannibalization of the existing proposal, and effect of possible inflation are a few of the topics requiring further investigation.

In phase 3, (Selection) which is the most analysed phase also contain neglected elements, for example, the rationale for the various methods used, measurement the cost of capital, the choice of a risk-free rate of risk adjustment for the capital investment, 
DOI: 10.14807/ijmp.v11i7.1231

sophistication of techniques, capital rationing, details of the level of authorization, etc. And in the last Stage 4, (Control) research needs to be carried out into the performance appraisal process, (i.e. how the company gets to know the performance). the procedures of control, and the provision of reward for performance. This was a brief selection of research questions that future researchers need to answer in their research studies (MUKHERJEE, 1987).

Kim (1979) was one of the earliest researchers who realized that researchers usually concentrate on the third phase of the capital budgeting process which is selecting and ranking of alternative capital investment opportunities. His opinion was later corroborated by Scott and Petty (1984) that researchers invest most of their time on a specific stage of the capital investment process which is Project selection.

Gordon and Pinches (1984) drew emphasis on the need for examining the process of capital budgeting in its entirety and the same is the opinion not on a specific phase. Mukherjee (1987) who has seconded Gordon and Pinches' (1984) proposition and advised that a survey on the capital investment process needs to focus on the entire process rather than on individual element of capital budgeting. Hence, the rationale for the review of over forty years of research surveys in the area of capital investment to know the future interest areas founded and the areas that have been neglected.

\section{METHODOLOGY}

Grounded theory methodology was first time introduced by Barney Glaser and Anselm Strauss (1967), which was subsequently refined and further developed by Strauss and Corbin (1997), Clarke (2005) and Charmaz, (2006). The original version of grounded theory was inspired by the positivist paradigm which deals strictly on empirical data analysis and scientific verification of the phenomenon. Hennink et al. (2011) therefore describe grounded theory as a reliable approach that provides a scientific and rigorous method in qualitative research.

Charmaz (2006) therefore developed the constructive approach to grounded theory in which the author emphasized the relationship between the researcher and the construct as the outcome of the study. Charmaz (2006) and Stewart (2006) has referred to the interview as the most suitable tool for grounded theory. Interviewee allows us the opportunity to understand the reality of the practices and the actual phenomena, feelings, responsibilities, and most important allows insight into the information that is required for exploring and understanding the issues.

Holton (2007) has referred to grounded theory as the most suitable research approach that undertakes an exploratory type of research towards developing a theory. Similar is the opinion of Clarke (2005) who emphasizes that the grounded theory approach is the finest 
DOI: 10.14807/ijmp.v11i7.1231

approach for generating a theory to understand the existing issues or unexplored areas of a problem. According to Strauss and Corbin (2014), grounded theory is used to develop a theory from existing data which is systematically obtained, analysed and evaluate through a proper process of research. This is the reason that grounded theory is considered as one of the most reliable and appropriate methods for qualitative research.

According to McCallin (2004), grounded theory has multiple versions and models with some being considered as more reliable to use as far as exploratory research and developing a theory is concerned. This was endorsed by Fisher (2004) that there are many ways in grounded theory to explore the problem. Strauss and Corbin (1997) elaborate that the problem may be defined at the start of the study that was contradicted by Glaser (1967). The reason of contradiction is the following major issue for instance; Clarke (2005) and Charmaz (2006) highlighted that constructivist grounded theory commenced with the identification of the problem area rather than the predicated theory, thus allowing the researcher to use reflexibility their own interpretation skills to understand the theoretical implications.

The Constructivist version of Grounded theory is less rigid and more flexible in contrasting to the initially developed grounded theory (STRAUSS; CORBIN, 1990; STRAUSS; CORBIN, 1997). Therefore, in this study constructivist grounded theory applied to explore the appraisal process od Capex decisions.

\subsection{Data sample}

Tie, (2019) endorsed that theoretical sampling should be used to develop theory through constructivist grounded theory. Hence, this study based on theoretical sampling on the bases of the following criteria: First, these interviewees are the representative of the corporates, listed in the Pakistan stock exchange. Second, listed companies' interviewees subcategorized by major sector of Pakistan Stock Exchange-100 index. For instance (Oil and Gas, Fertilizer, Cement, Textile, Pharmaceuticals, and others). Third, the representative of the listed companies must be CFO or senior experts who have knowledge of the long-term investment.

Therefore, the selected sample in this study is the true representation of the population. 48 in-depth interviews were conducted by the corporate experts, and 48 unstructured interviews were recorded that were 3,840 minutes long altogether. These interviews were converted into text, these texts summed up to 205,010 words. After transcription of all of the interviews, NVIVO software was used for analysis.

\subsection{The process and procedure}


DOI: 10.14807/ijmp.v11i7.1231

Constructive grounded theory approach used in the study to explore the capital investment appraisal process. Figure 1 outlines the multiple stages of the constructivist grounded theory methodology. It is important to note here the difference between the grounded theory and other qualitative research approaches that in grounded theory data collection and data analysis are merged and performed after each cycle of an interview.

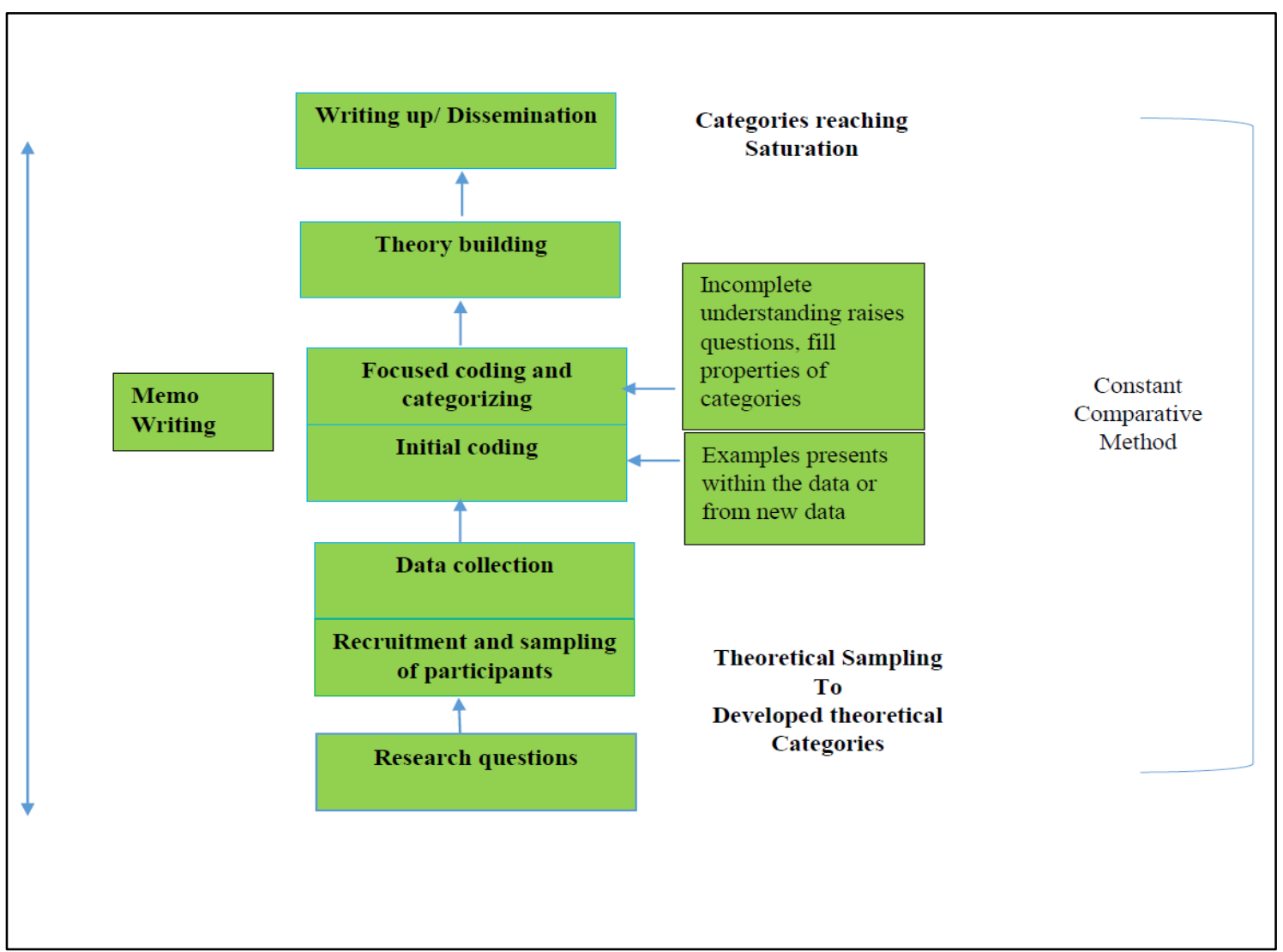

Figure 1: adopted from Charmaz (2014) this schematic diagram shows data collection and analysis procedure which is used in this thesis.

\section{FINDINGS}

These comprehensive open-ended questions covered the problem related to an appraisal process of capital investment in Pakistan. Table 2 shows the participants' attributes of a sample in terms of gender, age, position, experience, level of education, and the number of employees working in the company. 
DOI: 10.14807/ijmp.v11i7.1231

Table 2: Demographics of sample interviewees

\begin{tabular}{lll}
\hline Attributes & No of Participants & Response \% \\
\hline Gender & 36 & $75 \%$ \\
Male & $\mathbf{1 2}$ & $25 \%$ \\
Female & & \\
Age & 0 & $0 \%$ \\
Less than 25 years & 9 & $18.75 \%$ \\
25 to 35 years & 38 & $79.2 \%$ \\
36 to 55 years & 1 & $2 \%$ \\
More than 55 years & & \\
Position & 31 & $64.5 \%$ \\
CFO & 2 & $4.2 \%$ \\
CEO & 7 & $14.5 \%$ \\
Director & 8 & $16.5 \%$ \\
Others & & \\
Experience & 12 & $25 \%$ \\
1 to 5 Years & 13 & $27 \%$ \\
5 to 10 Years & 18 & $37.5 \%$ \\
10 to 15 Years & 05 & $10.5 \%$ \\
15 and More & & \\
Level of Education & 0 & $0 \%$ \\
Graduation & 6 & $12.5 \%$ \\
Master & 26 & $54 \%$ \\
CA & 11 & $23 \%$ \\
ACMA & 5 & $10.4 \%$ \\
Others & & \\
No. of employees & 9 & 18.75 \\
Below 500 Employees & 08 & 16.75 \\
500 to 1000 Employees & 14 & 29.1 \\
1000 to 1500 Employees & 17 & $35.4 \%$ \\
Above 1500 Employees & & \\
\hline
\end{tabular}

Table 2 depicted the following demographic outcome which is necessary to analyze the results: The male and female proportion in the respondent was $75 \%$ and $25 \%$, respectively; the age categories explain that the major part of the sample was 36 to 55 years, which shows the majority interviewees are seniors (79.2\%) which is good because experience was essential in sample selection. The second age category was 25 to 35 years, which was $18.75 \%$ and only 1 representative was more than 55 years old which is $2 \%$ of the total sample and there was no one under 25 in the sample.

As far as the designation of representatives is concerned, most interviewees were CFO of their firms which is $64.5 \%$. The second designation category is approximately equal to the Director and other categories which were $14.5 \%$ and $16.5 \%$ of the sample respectively. The experience was very important for this study, hence the representatives chosen for this study have a long industry experience in the context of CAPEX. Interviewees with 10 to 15 years are the major part of our sample (37.5\%) followed by 5 to 10 years experience (27\%), less than 5 years (25\%), and more than 15 years (10.5\%). 
DOI: 10.14807/ijmp.v11i7.1231

The responses to level of education were very interesting, the majority of representatives are CA (Chartered Accountant) which is $54 \%$ of the sample, then ACMA (Associated Cost and Management Accountant), which is 23\%. Master degree holders are also part of this interview process were $12.5 \%$, while other categories were $10.4 \%$ that included people who have degrees like CFA or professional diploma and certifications, etc. The size of a firm refers to the number of employees in the selected firms; the majority of sample firms (35.4\%) are from firms with more than 1500 employees. 29.1\% of the firms have 1000 to 1500 employees. $16.75 \%$ of the firms have 500 to 1000 the number of employees and $18.75 \%$ have less than 500 employees.

According to the constructed ground theory methodology, first in-depth interviews are conducted; after conducting an interview it is encoded line by line in the first stage which is known as initial coding, then come the focused coding then categorizing, subsequently developing a conceptual model. Then the theoretical saturation is tested and after developing the conceptual model, the final theoretical model is designed and elaborated.

\subsection{Initial coding}

Initial coding is a process, where the basic concept is developed from the available sample and then categories are prepared. In this process, "a" used as the label for the original statement in large available samples. After that, "aa” used for the refined concept which is drawn from the classification and abstraction form initial label. Finally, by the classification and abstraction, code "A" used for the initial category. With the help of conceptualization and categorization, data are transformed into the same concept and category from the original material. In order to explore and for refined, in-depth coding, 38 concept and 19 categories are obtained from the initial coding of 48 cases.

\section{Appendix A shows an example to explain the initial coding of this study}

The initial concept which is developed from initial coding in Appendix A is merged constantly. At this stage 38 concepts and 19 categories obtained from the initial coding of 48 cases. The following Appendix B shows a summary to explain the stage clearly.

\section{Appendix B. Summary merged initial categories}

\subsection{Focused coding}

The purpose of the focused coding process is to emphasize the theme and pattern with the in-depth meaning of data. Through this process categorizing and abstracting from the initial coding developed in Appendix A. This focused coding defines similarities and dissimilarities 
among the various developmental themes in the research study. This stage gives the opportunity to rethink the specific topic, regrouping and categorizing to develop appropriate meaning from the responses. This phase of the study classifies 19 initial categories into 09 . Following are the focused coding shows in Appendix C.

\section{Appendix C The main categories form-focused coding}

The above appendix $C$ shows the focused coding; categorized from the initial concept in Appendix B. Appendix B shows the 19 categories from 205 initial concepts, now through the rethinking process 9 main categories developed through focused coding. For instance, all multiple analyses are combined into one category known as "Analysis". Traditional evaluation techniques and real options analysis are used for selection purposes. Therefore, it combined into the "Selection" stage. Multiple modes of financing are used for CAPEX (i.e.) Three modes; debt financing, equity financing and Islamic assets-based financing are merged into one category which is known as "Mode of Financing". Monitoring and controlling somehow provided a similar theme therefore it combined with the name of "Monitoring and Control".

\subsection{Derivation of Capex Appraisal Model (CAM)}

Charmaz (2006), stands on her solid argument that the theory depends on the researcher's understanding and his view on the subject. Moreover, it cannot stand outside its decided boundaries, and numbers of the researchers may present the same idea while they may differ from each other on the ground theoretical aspect. The beauty of the constructivist grounded theory is that it always takes a reflexive position for the whole research process and interested in how theories evolve. Many researchers are Bryant (2007), Charmaz (2000), Hall and Callery, (2001) and Reis et al. (2007) have established their argument regarding constructivist grounded theorists that both data and analyses are based on real and social constructions that directly and indirectly reflect.

Charmaz (2014) argued that all analysis is situated in place, culture, time and even multiple situations. Because any constructivist observes reality and facts, even value of issue as linked, and admitted that what they can see or what they cannot incorporate in the rest of the values. Therefore, the approach aware and they know in this way, constructivists try to become aware of their assumptions and face their impact on research.

They realize that well-established theorists can ironically import predetermined ideas to work when they are not aware of their initial assumptions. Therefore, constructivism favours the reflectiveness of researchers towards their interpretation as well as their study participants. Moreover, (CHARMAZ, 2000; GUBA; LINCOLN, 1994; SCHWANDT, 1994) mentioned 
DOI: 10.14807/ijmp.v11i7.1231

that the theory which is developed after so many efforts, always give the interpretative portray of the issue not the exact view of the situations.

Therefore, an appraisal process of capital investment decision is a multi-layered process and somehow it is very complicated to cover the whole process in a model. After conducting the comprehensive interviews and following the protocol and procedures which is prescribed in constructive grounded theory by Charmaz (2006), for instance, initial coding, focused coding, theoretical sampling and categorisation. Now, after following the prescribed procedure of constructivist grounded theory, Capex Appraisal Model (CAM) derived which is given below in Figure 2.

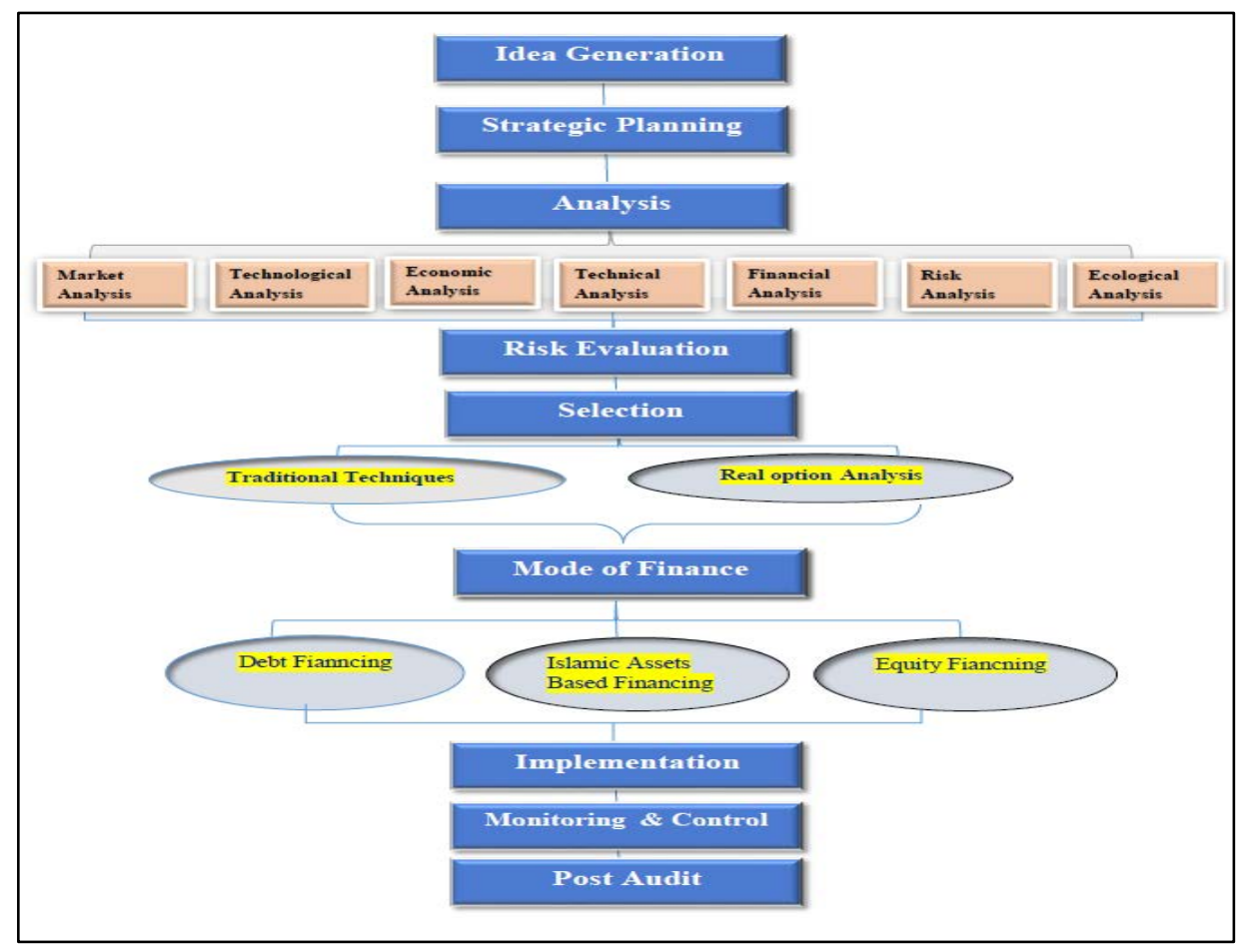

Figure 2: Derived Model: Capex Appraisal Model (CAM)

According to this derived model Figure 1 depicting the relationships among the prescribed stages. An appraisal of the capital investment decision process may be divided into 9 extensive steps. These steps are; Idea generation, Strategic Planning, Analysis, Risk Analysis, Selection, Mode of finance, Implementations, Monitoring and control, and Post-audit.

In the above section, the explored appraisal process of capital investment decision is described gradually. This section is imperious to compare all explored stages with the previous findings of the past researchers to authenticate the findings of the current study. The main purpose of this section is to explain current findings through triangulation.

Table 3: Process of Capital Investment Decision-Making in Stages comparisons

\begin{tabular}{c}
\hline King (1975) \\
\hline CC (7)
\end{tabular}


INDEPENDENT JOURNAL OF MANAGEMENT \& PRODUCTION (IJM\&P)

http://www.ijmp.jor.br

v. 11, n. 7, November - December 2020

ISSN: 2236-269X

DOI: 10.14807/ijmp.v11i7.1231

\begin{tabular}{|c|c|c|c|c|c|}
\hline Triggering & Identification & Creation & $\begin{array}{l}\text { Generation of } \\
\text { idea }\end{array}$ & $\begin{array}{l}\text { Determination of } \\
\text { budget }\end{array}$ & Planning \\
\hline Screening & Development & Decision & $\begin{array}{l}\text { Development of } \\
\text { proposal }\end{array}$ & $\begin{array}{l}\text { Search and } \\
\text { development }\end{array}$ & Analysis \\
\hline Definition & Selection & Implementation & $\begin{array}{l}\text { Project } \\
\text { Classification }\end{array}$ & Evaluation & selection \\
\hline $\begin{array}{l}\text { Evaluation } \\
\text { Transmission }\end{array}$ & Control & Control & $\begin{array}{l}\text { Screening } \\
\text { Appraisal }\end{array}$ & $\begin{array}{l}\text { Authorization } \\
\text { Monitoring and } \\
\text { control }\end{array}$ & $\begin{array}{l}\text { Financing } \\
\text { implementation }\end{array}$ \\
\hline Decision & & & $\begin{array}{l}\text { authorization } \\
\text { Post Audit }\end{array}$ & & Review \\
\hline
\end{tabular}

The new findings of this current study are based on nine extensive stages. While the nine stages look like the above stages which are explored by previous researchers, the differences among stages are on the basis of priority; for instance, $1^{\text {st }}$ stage of current findings based on "Idea Generations" which endorses the extensive findings of the previous study. Similarly, King (1975), Gitman and Forrester (1977), Pinches (1982), McIntyre and coulthurst (1985) and Arnold (2008) although used different nomenclature for the $1^{\text {st }}$ stage but the meaning of their $1^{\text {st }}$ stage is related to idea generation. Interestingly, Arnold (2008) specified and used the same nomenclature for stage one which is 'idea generation'.

In the second stage, the current study is related to "Strategic Planning", which is identical to the $1^{\text {st }}$ stage of Prassana (2016) who considered planning is the first stage in his suggested model. However, in a current study exploration, it comes after idea generation as the second stage. The third stage is discovered as "Analysis”, and this stage is endorsed by Chandra (2014) as the second stage with the same nomenclature, although King (1975), Gitman and Forrester (1977), Pinches (1982), McIntyre and coulthurst (1985) and Arnold (2008), consider analysis stage although they used different taxonomy.

Risk Evaluation is discovered as a new stage separately in this current study. Although, previous researchers considered risk analysis as a core part and covered in the analysis or development phase. Nevertheless, in this forecasted process risk evaluation is an exclusively new stage to renew and review again the risk parameter with multiple tools before the selection stage. Selection is the fifth stage of the prescribed suggested model and this is a very known and most attractive stage for the past researchers. Therefore, this stage of selection is common to all processes of capital investment decisions. Table 5 depicted the Position of the selection stage on various surveys.

However, an additional and unique finding is the part of this forecasted model that is selection process comprised of two major tools of selection analysis. First. Traditional techniques, which are covered by all the past researchers. Two, Real options analysis is added 
DOI: 10.14807/ijmp.v11i7.1231

in this model and suggested industry to use real options analysis for making the right decision at the right time. Real options analysis is very supportive in the selection process and of course, it is very advantageous for the corporate sectors. Sixth stage is "Mode of Finance" in the suggested model; previous studies also mentioned this stage due to its importance. For instance, Pike and Neale (2009) considered the mode of finance as the first stage with the title of 'determination of budget'. Likewise, Table 5 shows it that other processes also have in it as a stage but on different levels.

Although the new findings are the part of this stage as Islamic assets based financing is going popular in Islamic and Non-Islamic states. This model suggests that when a corporation is going to decide the mode of finance, the option of Islamic finance should be in the mind and compared with other modes, sometime it may be workable, particularly in uncertain situations. The seventh stage of the proposed model is "Implementation" this stage is also explored by Chandra (2014). Table 3 shows that the implementation stage incorporated by past researchers in their studies. However, this could be reflected in different terminologies.

Monitoring and control is the eight-stage in the prescribed model and Pike and Neale (2009) represent it to and consider it as a significant phase. The post-audit stage is placed the ninth-stage in the prescribed model and this stage is the major stage in previous researches. for instance, Arnold (2008) mentions post-audit as the last significant stage to know the reality of the capital investment decisions and this stage can overcome issues for future investment.

Furthermore, Table-5 is depicting the number of major survey findings as compared to the forecasted model for appraising long term investment decisions.

\section{CONCLUSION}

The purpose was to developed theory and explore the appraisal process of capital investment decisions. In this study constructivist grounded theory approach adopted for exploration of the objective. In the first stage, 48 in-depth interviews were conducted from finance executives of listed companies Pakistan stock exchange. Interviews recording was consisting of 3,840 minutes. These interviews converted into text; these texts consist of 205,010 words. After transcription of all of the interviews, NVIVO software was used for analysis.

Theoretical sampling used in this study; initially, 35 concepts and 19 categories were obtained from the initial coding of 48 cases. In the next stage, using focused coding, we classified 19 initial categories into 09 categories. These 09 categories represent each stage of 
DOI: 10.14807/ijmp.v11i7.1231

the appraisal process of capital investment. These stages are Idea generation, Strategic planning, Analyses, Risk Evaluation, Selection, Mode of finance, Implementation, Monitoring and control, and Post-audit.

Idea generation is the $1^{\text {st }}$ suggested stage, the research and development department or business process division must exclusively work for this stage. Even these sections of business should be responsible for gathering all the new relevant ideas from a lower level to top management. According to the findings of this study, the second stage of the process is "strategic planning" which is the core stage of the whole process of the appraisal process. Moreover, Qualitative factors are an integral part of the second stage of the prescribed model.

The third stage is "Analyses" which is related to discovering critical matters in investment opportunities and to prepare feasibility regarding multiple available capital investment options to select the best one to take further action. The fourth suggested stage in the model is "risk evaluation" the purpose of incorporation of this stage is to review proposal for the second time. Risk is a central issue for developed countries in general and particularly developing countries. In the current era, the number of risks categorized and faced by corporate to instigate any project.

The fifth stage of this suggested model is the "selection" stage. This suggested model classified this selection stage into two categories. 1. Traditional techniques 2. Real options analysis. Traditional techniques are further classified into discounted and non-discounted techniques that are currently not covered by all the dynamics of the contemporary world. However, it does not mean that traditional techniques may completely be relinquished from the selection stage. Moreover, to support the analysis and provide finest recommendation regarding the capital investment decisions, Real options analysis should be conducted to make the best decisions for the company's future.

The sixth stage is "Mode of Finance". Traditionally, we have debt and equity finance options. However, in exploring the reality we found that Islamic assets based finance is also a valuable option for corporates. Moreover, there are numerous corporations that are utilizing this approach due to various reasons; for instance, the Islamic mode of finance always creates real assets for the corporation and the economy as compared to the traditional banking system.

The seven-stage is "implementation", which is a very crucial stage for the process, in this stage top management always involves to review the procedure of implementing the 
DOI: 10.14807/ijmp.v11i7.1231

projects. In the implementation stage, multiple barriers become hurdles in implementing plans. This stage actually deals with random and abrupt activities and gives counter-strategies.

The eight-stage is "monitoring and control". Through this stage, executors are observing the standard plan and consequences of the actual performance. How much deviation has happened and what is the threshold level to counter it. Top management should participate and must be supportive to control abrupt variations in executed capital investment decisions.

Moreover, the last ninth stage of the suggested model is "Post Audit". The company may observe many things in this stage, and discoveries of the findings of this stage are usually used to overcome the difficulty levels and mistakes which happen from planning to implementing stage. Even a number of challenges in the future's capital investment decisions may be resolved. Top management should be perfectly updated with the auditors of the project to know the actual gaps and fill it according to the need of the projects

Therefore, the development of appraisal process stages is the novelty of this study and key theoretical contribution. It provides an in-depth understanding step by step that how industry appraised capital investments. It is the new knowledge for academia, addition in literature and reduces the gap between the corporate world and academia.

\section{REFERENCES}

AKALU, M. M. (2001). Re-examining project appraisal and control: developing a focus on wealth creation. International Journal of Project Management, v. 19, n. 7, p. 375-383.

AL-AJMI, J.; AL-SALEH, N.; HUSSAIN, H. (2011) Investment appraisal practices: A comparative study of conventional and Islamic financial institutions. Advances in Accounting, v. 27, n. 1, p. 111-124.

ANDOR, G.; MOHANTY, S. K.; TOTH, T. (2015) Capital budgeting practices: A survey of Central and Eastern European firms. Emerging Markets Review, v. 23, p. 148-172.

ANDREWS, G. S.; BUTLER, F. (1986) Criteria for major investment decisions. Investment Analysts Journal, v. 15, n. 27, p. 31-37.

ARGENTI, J. (1977) Company Failure-Long Range Prediction Not Enough. Accountancy, v. 88, n. 1008 , p. $46-52$.

ARNOLD, G. (2008) Corporate financial management. Harlow Pearson Education. 4th ed. BALDENIUS, T. (2003) Delegated investment decisions and private benefits of control. The Accounting Review, v. 78, n. 4, p. 909-930.

BASU, A. K.; DREW, M. E. (2010) The appropriateness of default investment options in defined contribution plans: Australian evidence. Pacific-Basin Finance Journal, v. 18, n. 3, p. 290-305.

BRYANT, A.; CHARMAZ, K. (Eds.) (2007) The Sage handbook of grounded theory. Sage. 
BURNS, R.; WALKER, J. (2009) Capital Budgeting Surveys: The Future is Now. Journal of Applied Finance, v. 19, n. 1/2.

CHANDRA, P. (2014) Project planning, analysis, selection, financing, implementation and review. McGraw Hill Education; 8 edition

CHARMAZ, C. (2006) Constructing grounded theory, a practical guide through qualitative analysis. Thousand Oaks: Sage.

CHARMAZ, K. (2000) Constructivist and objectivist grounded theory. In DENZIN, N.; LINCOLN, Y. (Eds.) p. Handbook of Qualitative Research, Second Edition, Second, p. 509536, Thousand Oaks, CA: Sage.

CHARMAZ, K. (2014) Constructing grounded theory. London: Sage.

CLARKE, E. (2005) Situational Analysis: Grounded Theory After the Postmodern Turn (2nd ed) Thousand Oaks, CA: Sage.

CORBIN, J.; STRAUSS, A. (2014). Basics of qualitative research: Techniques and procedures for developing grounded theory. Sage publications.

CORREIA, C. (2012). Capital budgeting practices in South Africa: A review. South African Journal of Business Management, v. 43, n. 2, p. 11-29.

DOUMPOS, M.; ZOPOUNIDIS, C. (2014) Introduction to financial decision making. In Multicriteria Analysis in Finance, p. 1-10, Springer.

EHRHARDT, M. C.; BRIGHAM, E. F. (2016) Corporate finance: A focused approach. Cengage learning.

ELJELLY, A.; ABUIDRIS, A. (2001) A survey of capital budgeting techniques in the public and private sectors of a less developed country (LDC) in the case of Sudan. Journal of African Business, v. 2, n. 1, p. 75-93.

FISHER, C.; BUGLEAR, J. (2004). Researching and writing a dissertation for business students. Financial Times Prentice Hall.

GITMAN, L. J.; FORRESTER, J. R. (1977) A Survey of Capital Budgeting Techniques Used by Major U.S. Firms, Financial Management, v. 6, n. 3, Fall, p. 66-71.

GLASER, B. G.; STRAUSS, A. L. (1967) The discovery of grounded theory. Chicago: Aldrin.

GORDON, L. A.; PINCHES, G. E. (1984). Improving capital budgeting: A decision support system approach. Addison Wesley Publishing Company.

GUBA, E. G.; LINCOLN, Y. S. (1994) Competing paradigms in qualitative research. In

DENZIN, N. K.; LINCOLN, Y. S. Eds., p. Handbook of qualitative research, p. 105-117. Thousand Oaks, CA: Sage.

HALL, W. A.; CALLERY, P. (2001) Enhancing the rigor of grounded theory: incorporating reflexivity and relationality. Qualitative Health Research, v. 11, n. 2, p. 257-72.

HENNINK, M.; HUTTER, I.; BAILEY, A. (2011) Qualitative research methods. London: Sage.

HOLMES, T. (1998). How Important Is Variety and Returns to Scale; What Can We Learn from Local Demand. Mimeo, University of Minnesota

HOLTON, J. A. (2007). The coding process and its challenges. The Sage handbook of grounded theory, (Part III), 265-89. 
KEASEY, K.; WATSON, R. (1989) Consensus and accuracy in accounting studies of decision-making: A note on a new measure of consensus. Accounting, Organizations and Society, v. 14, n. 4, p. 337-345.

KENGATHARAN, L. (2016) Capital Budgeting Theory and Practice: A Review and Agenda for Future Research. Applied Economics and Finance, v. 3, n. 2, p. 15-38 10.11114/aef.v3i2.1261.

KIM, S. H. (1979) Making the Long Term Investment Decision, Management Accounting, v. 60 , n. 9, p. 41-49.

KING, P. (1975) Is the Emphasis of Capital Budgeting Theory Misplaced? Journal of Business Finance \& Accounting, v. 2, n. 1, p. 69-82.

KLAMMER, T. (1973) The association of capital budgeting and firm performance. The Accounting Review, v. 48, n. 2, p. 353-364.

KLAMMER, T.; WALKER, M. (1984) The continuing increase in the use of sophisticated capital budgeting techniques. California Management Review, v. 27, n. 1, p. 137-148.

LUMBY, S.; JONES, C. (1999) Investment Appraisal and Financial Decisions, $6^{\text {th }}$ edition International Thomson Business Press

MADURA, J. (2020) International financial management. Cengage Learning.

MALENKO, A. (2019). Optimal dynamic capital budgeting. The Review of Economic Studies, v. 86, n. 4, p. 1747-1778.

MAROYI, V.; VAN DER POLL, H. M. (2012). A survey of capital budgeting techniques used by listed mining companies in South Africa. African Journal of Business Management, v. 6, n. 32, p. 9279-9292.

MCINTYRE, A. D.; COULTHURST, N. J. (1985) Theory and Practice in Capital Budgeting. The British Accounting Review, Autumn, p. 24-70.

MINTZBERG, H.; RAISINGHANI, D.; THEORET, A. (1976) The Structure of 'Unstructured' Decision Processes. Administrative Science, Quarterly 21, p. 246-275.

MUKHERJEE, T. K. (1987) Capital-Budgeting Surveys: The Past and the Future, Review of Business and Economic Research, v. 22, n. 2, Spring, p. 37-56.

MUKHERJEE, T. K.; VINEETA L. H. (1999) Capital-Rationing Decisions of Fortune 500 Firms: A Survey, Financial Practice and Education, v. 9, n. 1, Spring/Summer, p. 7-15.

MUKHERJEE, T.; BAKER, H.; D'MELLO, R. (2000) Capital Rationing Decisions of Fortune 500 Firms - Part II. Financial practice and education, v. 10, n. 9.

PETROVIĆ, E.; RADOVIĆ, O.; STANKOVIĆ, J. (2013) Individual investors' investment decision-making process. Strategic Management, v. 18, n. 1, p. 3-14.

PIKE, R. H. (1996) A longitudinal survey on capital budgeting practices, Journal of Business financing and Accounting, v. 23, n. 1, p.79-92.

PIKE, R. H. (1988) An empirical study of the adoption of sophisticated capital budgeting practices and decision-making effectiveness, Accounting and Business Research, v. 18, Autumn, p. 341351.

PIKE, R.; NEALE, B. (2009) Corporate finance and investment decisions and strategies, 6th edn.; Harlow: Pearson Prentice Hall. 
PINCHES, G. E. (1982) Myopia, Capital Budgeting, and Decision Making. Financial Management, v. 11, n. 3, p. 6-19.

REIS, S.; HERMONI, D.; VAN-RAALTE, R.; DAHAN, R.; BORKAN, J. M. (2007) Aggregation of qualitative studies-From theory to practice: Patient priorities and family medicine/general practice evaluations. Patient education and counseling, v. 65, n. 2, p. 214222.

REMER, D.; NIETO, A. (1995) A Compendium and Comparison of 25 project evaluation techniques. International Journal of Production Economics, v. 42, n. 1, p. 79-96.

SCHWANDT, T. A. (1994) Constructivist, interpretivist approaches to human inquiry. In DENZIN. N. K.; LINCOLN, Y. S. (Eds.), Handbook of qualitative research, p. 118137. Thousand Oaks, CA: Sage

SCOTT JR., D. F.; WILLIAM PETTY II, J. W. (1984) Capital Budgeting Practices in Large American Firms: A Retrospective Analysis and Synthesis, The Financial Review, v. 19, n. 1, p. 111123.

SLAGMULDE, P.; BRUGGEMANA, W.; WASSENHAVEB, L. (1995) An empirical study of capital budgeting practices for strategic investments in CIM technologies. International Journal of Production Economics, v. 40, n. 1, p. 121-152.

STEWART, C.; CASH, W. (2006) Interviewing: principles and practices. New York: McGraw-Hill.

STRAUSS, A.; CORBIN, J. (19978) Basics of qualitative research: techniques and procedures for developing grounded theory. Thousand Oaks: Sage.

THORNE, S. E.; JENSEN, L. A.; KEARNEY, M. H.; NOBLIT, G.; SANDELOWSKI, M. (2004) Qualitative metasynthesis: reflections on methodological orientation and ideological agenda. Qualitative Health Research, v. 14, n. 10, p. 1342-65.

TIE, Y. C.; BIRKS, M.; FRANCIS, K. (2019) Playing the game: A grounded theory of the integration of international nurses. Collegian, v. 26, p. 470-476.

TOIT, M. D.; PIENAAR, A. (2005) A review of Capital Budgeting Behavior of South African firms. Meditrari Accountancy Research, v. 13, n. 1, p. 19-27.

VAN HORNE, J. C.; WACHOWICZ, J. M. (2013) Fundamentals of financial management, Pearson Education Limited Edinburgh Gate Harlow Essex. $13^{\text {th }}$ edition

VERBEETEN, F. H. (2006) Do organizations adopt sophisticated capital budgeting practices to deal with uncertainty in the investment decision? A research note. Management

Accounting Research, v. 17, n. 1, p. 106-120.

Appendix A: Shows an example to explain the initial coding of this study.

\section{Original sample}

a1. Pakistan's economic situation has been affecting long and short term investment decisions since continuously devaluation of the currency, interest rate, exchange rate, and other issues have been quite disturbing for the industry. The situation is now improving in the 2nd Quarter of 2019-2020, as it is much better for the cement sector and I don't know how but our demand again is increasing and we are on the way to achieve our goals and targets.

a2. At present, nobody can claim that the economic situation is good from the country's perspective. However, it is sad for all the corporates that we as a nation are not very serious to do something good and work on fast recovery from this turmoil. We are working as a company on

\begin{tabular}{|c|c|}
\hline Initial concept & Initial category \\
aa1. Economic & \\
Situations & \\
The expectation & \\
from Government & \\
Companies & \\
performances & \\
a1,a2,a11, & A1.Economic \\
& analysis \\
& aa1, aa2 \\
\end{tabular}


INDEPENDENT JOURNAL OF MANAGEMENT \& PRODUCTION (IJM\&P)

http://www.ijmp.jor.br

v. 11, n. 7, November - December 2020

ISSN: 2236-269X

DOI: 10.14807/ijmp.v11i7.1231

very serious issues and want to do something for this nation. Moreover, this sector will do its best for improving the current situation; the Prime Minister of Pakistan has taken serious initiative for the future of Pakistan.

a11. It will be good for this sector due to friendly policies as we observed this new Government is relatively better as compared to the previous Governments. Presently economic situation is not good, as we were expecting it to improve. Our expectations couldn't be fulfilled as we were expecting a lot from this Government. We have to plan accordingly to boost our company of course for the interest of all concerned stakeholders of the company.

It will take at least 2-3 years in my personal opinion to see the results.

a12. Yes, economic policies, directly and indirectly, impact on Capex investment policies of the company. However, we are ready to face the upcoming challenges. But as far as impact is concerned, we can say it created a negative impact but now situations are changing we are very serious towards achieving highly intensive capital investment. Yes, we are moving towards new capital investment for the corporate and as far as my experience and feelings are concerned, I can say the future of Pakistan is very bright. Moreover, CPEC will be beneficial in the context of CAPEX.

a21.Basically, the economic situation is not very well from the company perspective. Yes, it is a continuous process, and at present, we are planning and dealing with many CAPEX decisions. We evaluate the key factors that contribute to a positive outlook. We are hopeful and optimistic that good times will come but after some interval.

a31. Idea generation does matter and it is very important for the company's future as well; there could be several reasons but at times the main reason behind such an initiative could be the competition. It matters because we are under the control of Government therefore we have to work accordingly.

a36. The idea is the key part of Strategic Planning for the Company.

a37. Idea initiation also matters and it is very important for the company future as well. A good idea always sets the direction of the business. I can comment on it in very simple terms that usually "need of investment" is the motivation for idea generation in our company.

a38. Pakistan follows the developed world, so the idea comes from the new things happening in the world. And as far as idea generation is concerned there are no specific rules, but yes, mostly ideas from the top management are quickly implemented and approved

a40. No one can reject the importance of the idea. It is very important, of course, the idea is the key element to open your success gateway. There are no boundaries for generating the idea. Many existing industry downfalls give us an idea, competitions, technical expertise, and even research work that may give us an idea to win the market competition

aa2. Economic conditions supportive for investment a12, a21

aa3. Investment Idea a31,a36,a37

aa4. Importance of Idea a38,a40
A2. Idea Generation aa3, aa4 
a41. Market analysis is very crucial to know the reality of project demand in the market. We usually consider and conduct market analysis before taking approval from the higher authority. Market analysis is somehow deal with the scope of production or returns of the capital investment.

a44. Multiple analysis is required to prepare feasibility for long term investment decisions for instance; market analysis, economic analysis, technical analysis, etc. Without knowing qualitative abstract we would be unable to draw conclusions regarding the importance of any investments.

a47. Analysis regarding the market is one of the key analyses, although a number of analyses has to be done for evaluating capital investment. This analysis comprehensively covers the market potential and share of the market.

a48. The analysis is the most important second step after idea approval, most demanding analyses are market analysis, economic analysis, ecological analysis, technical analysis and many more.

a49. The analysis is the core part of the process of any CAPEX. But there is no proper standard where you may list down the analysis, but, hmm... sure there are a number of analyses which are common and key analysis to be done.

a52. To understand the market is the expertise of evaluators, even idea generation is somehow based on the understanding of the market. Understanding gives you forecasting ability to judge market feasibility and the future of long term investment

a53. Capital investment should be compatible with the technical support, number of capital investments couldn't come to Pakistan due to lack of support of technical staff.

a55 Technically, sound CAPEX always worthwhile for company perspectives, therefore CAPEX should be appraised on the grounds of technical parameters.

a57. Long term investment, many times in Pakistan failed due to technical and technological weakness. Therefore, the industry now has brilliant minds who incorporate the upcoming challenges and know how to deal with it. However, we require strong analysis for this.

a60. CAPEX should be sound on technical ground, many times CAPEX is evaluated on the financial ground only which is not appreciable. Financial analysis is very vital for any capital investment decisions. But technical analysis should be conducted to understand the values and worth of current situations.

a66. As I have mentioned earlier that it depends upon the nature of analysis and what is required. Therefore technical analysis is also important as risk analysis is important for evaluating long term investment.

a67. Financial analysis is the backbone for any long term investment decision. This analysis basically provides us the understanding that how much this CAPEX is progressive.

a69. Financial evaluation of any long term investment covers the risk and return of any investment. Without knowing the values of risk and return you cannot make decisions.

a70. Selection of investment is a very different stage where you have to use discounted and non-discounted techniques. In this section, you have to work quantitatively and theoretically as well to make sure that the return portion should be higher as compared to the risk.

a71. A financial appraisal is a comprehensive separate stage but as far as analyses are concerned, it is always required to do it for a feasibility point of view. In this analysis, risk and return is the focus. aa5. Market Analysis is the key to evaluate CAPEX a41,a44,a47

aa7. Technical updated knowledge a53,a55,a57

aa6. Market potential and market share awareness a48,a49,a52

aa8. Technical support is vital for any long term investment a60,a66

A4. Technical Analysis aa7, aa8
A3.Market analysis aa5, aa6 aa9. Financial evaluation a67, a69

aa10. Risk and return a70,a71
A5 Financial Analysis aa9, aa10 
INDEPENDENT JOURNAL OF MANAGEMENT \& PRODUCTION (IJM\&P)

http://www.ijmp.jor.br

v. 11, n. 7, November - December 2020

ISSN: 2236-269X

DOI: 10.14807/ijmp.v11i7.1231

\begin{tabular}{|c|c|c|}
\hline $\begin{array}{l}\text { a72. Pakistan's corporate sector is required highly modern } \\
\text { technology to compete in the world. Technology price is too high, } \\
\text { therefore, we should be very conscious about advancement } \\
\text { technology before considering to invest in it. } \\
\text { a74. Technology review before the investment is to establish how } \\
\text { much technology is viable and reliable }\end{array}$ & $\begin{array}{l}\text { aa11. Technology } \\
\text { awareness is } \\
\text { compulsory before } \\
\text { taking decisions } \\
\text { a72,a74 }\end{array}$ & \multirow[t]{2}{*}{$\begin{array}{l}\text { A6. Technological } \\
\text { Analysis } \\
\text { aa11, aa12 }\end{array}$} \\
\hline $\begin{array}{l}\text { a72. Pakistan's corporate sector is required highly modern } \\
\text { technology to compete in the world. Technology price is too high, } \\
\text { therefore, we should be very conscious about advancement } \\
\text { technology before considering to invest in it. } \\
\text { a74. Technology review before the investment is to establish how } \\
\text { much technology is viable and reliable }\end{array}$ & $\begin{array}{l}\text { aa11. Technology } \\
\text { awareness is } \\
\text { compulsory before } \\
\text { taking decisions } \\
\text { a72,a74 }\end{array}$ & \\
\hline $\begin{array}{l}\text { a82. CAPEX evaluation cannot be possible without an assessment of } \\
\text { risk. Risk is the tool that is required to prepare a feasibility report } \\
\text { a84. Risk analysis covers uncertainty of future returns and cash flows } \\
\text { and many more things to make sure this project risk is manageable } \\
\text { or not. If it is manageable or controllable, then the further process } \\
\text { starts otherwise it should be closed immediately. }\end{array}$ & $\begin{array}{l}\text { aa13.Uncertainty } \\
\text { of cash flows and } \\
\text { returns must } \\
\text { measure to prepare } \\
\text { a feasibility report. } \\
\text { a82.a84 }\end{array}$ & \multirow[t]{2}{*}{$\begin{array}{c}\text { A7. Risk Analysis } \\
\text { aa13, aa14. }\end{array}$} \\
\hline $\begin{array}{l}\text { a86. Focusing risk is very significant as the financial appraisal is } \\
\text { important. Even I always suggest that risk measurement should be } \\
\text { explicitly done before the selection of any investment } \\
\text { a88. Risk analysis is not the controlling tool, initially, at the start we } \\
\text { do it for estimating risk situation otherwise risk issues must be dealt } \\
\text { separately where a number of tools of measuring risk should be } \\
\text { incorporated to handle risk issues. }\end{array}$ & $\begin{array}{l}\text { aa14. Risk is } \\
\text { essential as } \\
\text { financial analysis } \\
\text { a86,a88 }\end{array}$ & \\
\hline $\begin{array}{l}\text { a89. Environmental damages are sometimes ignored by industry } \\
\text { which is not good for us. Therefore, we have to work for it } \\
\text { a91. Restoration of damages of CAPEX is ultimately our } \\
\text { responsibility. Therefore crucial evaluation are required to address } \\
\text { this issue. }\end{array}$ & $\begin{array}{l}\text { aa15.environmental } \\
\text { damages and } \\
\text { restoration } \\
\text { a89, a91 }\end{array}$ & \multirow[t]{2}{*}{$\begin{array}{l}\text { A8. Ecological } \\
\text { analysis } \\
\text { aa15, aa16 }\end{array}$} \\
\hline $\begin{array}{l}\text { a94. Long term investment many times is very harmful to the health } \\
\text { of society. So, we should be very responsive to handle all the } \\
\text { damages for long term investment. } \\
\text { a97. We have to analyze the health environment of the project site } \\
\text { before implementation and after effect, continuously, for the } \\
\text { betterment of society and people who are affecting from the huge } \\
\text { CAPEX decision. }\end{array}$ & $\begin{array}{c}\text { aa16. Public health } \\
\text { a94,a97 }\end{array}$ & \\
\hline $\begin{array}{l}\text { a99. Strategic planning is the key part of the CAPEX investment } \\
\text { decision. Without planning no appraisal of any investment starts. } \\
\text { a101. The planning phase covers all aspect specifically qualitative } \\
\text { factors either this CAPEX is good for the company or society or } \\
\text { other stakeholders. }\end{array}$ & $\begin{array}{c}\text { aa17 Planning is } \\
\text { the essential phase } \\
\text { to start evaluation } \\
\text { CAPEX } \\
\text { a99, a101 }\end{array}$ & \multirow[t]{2}{*}{$\begin{array}{l}\text { A9. Planning } \\
\text { aa17, aa18 }\end{array}$} \\
\hline $\begin{array}{l}\text { a104. Planning phase focus at either long term investment is } \\
\text { worthwhile or not for the company prospective. } \\
\text { a107. Planning is the second phase of after good idea generation. } \\
\text { Planning starts as an idea generated in the company from any sources }\end{array}$ & $\begin{array}{l}\text { aa18 Planning has } \\
\text { measured the } \\
\text { worthiness } \\
\text { a104,a107 }\end{array}$ & \\
\hline
\end{tabular}


INDEPENDENT JOURNAL OF MANAGEMENT \& PRODUCTION (IJM\&P)

http://www.ijmp.jor.br

v. 11, n. 7, November - December 2020

ISSN: 2236-269X

DOI: 10.14807/ijmp.v11i7.1231

a105. Risk evaluation is one of the most important tasks before the selection phase. The reasons are evaluating the risk to measure and handle risk issues as quickly as possible

a110. Risk parameters are also evaluated in analysis phase, but specifically, we do risk evaluation through a number in the model to measure the risk parameters

a111. Risk measurement through quantitative means should be a separate stage to understand comprehensively the scope of any investments. Therefore, being Director Finance, I recommend observing Risk Appraisal before going to select any investment formally.

a116. Risk assessment is the separate stage in which sensitivity, decision tree, etc. are the analyses used by us to measure risk in the investments. As you know that we are working in a very volatile and unrealistic society. Therefore, these tools quantitatively present risk issues.

a117. The Selection stage is the noteworthy phase of an appraisal process of capital investment decisions. In this stage, a number of discounted and non-discounted methods are used to evaluate the CAPEX financial values.

a119. Pay-back; discounted payback, NPV, and IRR are used to measure the worth of any long term investments

a121. The selection phase is the most common stage which is the backbone of evaluating any long term investment.

a123. This selection phase provides us the opportunities to decide which options are the best option financially among various alternatives which are under-observation to select.

a124. Real options are also used for evaluating long term investment mostly to support the outcomes of discounted methods of selection a127. The number of developed counties used real options analysis for merger and acquisition purposes

a129. Real option practices are somehow used in complicated situations in Pakistan as such an industry needs to adopt it to improve the culture of decision making

a131. A Monte Carlo simulation is used in Pakistan to assessment and support the discounted method

a133. Other than the discounted method of evaluation Black-Scholes option pricing model is also used in appraisal context in complicated decisions making

a134. Equity financing is dependent upon the nature of investment do you have, market sentiments and investors' behavior also impact of deciding on IPOs

a136. The stock market future will be refined in the future, market awareness may be good in public, Government policies and strong governance will be the backbone for this sector, mode of equity does matter for long term investment decisions

a137. IPOs are dependent upon the cost of financing, many time equity valuations is a much better option for CAPEX. However, it depends upon the nature of CAPEX

a138. CAPEX through equity or any other financing depends upon the cost of financing as compared to Capex returns.

aa19. Risk measurement quantitatively a105, a110

aa21. Discounted and nondiscounted techniques used in evaluating the CAPEX a117, a119 aa22. The Selection phase is the essential phase of evaluating CAPEX a121, a123 aa23. Real options supports DCF a124, a127,a129

A12. Real options aa23. aa24

aa24 Real option methods a131, a133

aa25. Equity

financing is the option a134,a136

aa26. IPOs depended upon the cost of financing a137, a138
A10. Risk evaluation aa19,aa20

A11Traditional techniques aa21, aa22
A13. Equity financing aa25, aа26 
INDEPENDENT JOURNAL OF MANAGEMENT \& PRODUCTION (IJM\&P)

http://www.ijmp.jor.br

v. 11, n. 7, November - December 2020

ISSN : 2236-269X

DOI: 10.14807/ijmp.v11i7.1231

a139. Debt financing is the core source of finance, it is the easiest way as compared to equity financing which is somehow a complicated one. a141. Bank borrowing is the most useful approach in Pakistan, the industry considers it very easy to borrow from the bank and usually cost of debt are compared with the CAPEX returns.

a143. Debt financing is the largest option for arranging finance for CAPEX. Number of banks are ready to give you finance on CAPEX on very minimum conditions

a147. An increase in debt financing is directly impacted by WACC; an increase in debt financing is the reason for increasing the value of the firm and decline the cost of capital to some certain extent.

a151. They are one of the most important sources also available on very simple terms and conditions for CAPEX, that is the Islamic mode of finance.

a153. Islamic finance is relatively more valuable as compared to conventional banking loans.

a157. The Islamic mode of finance is a comparatively easy mode of finance as compared to other sources, However, it depends upon the nature of CAPEX as well.

a160. Risk management is also crucial as far as long term financing is concerned, Islamic mode financing have much better benefits as compare to conventional banking

a163. Implementation design plans are out once when the investment decision is approved by top management.

a165. Barriers to implementation activities are always countered through a specific strategy

a166. Top management is usually involved in every step of implementation

a168. The implementation phase is finally evaluated by financial and risk analysis.

stage.

a173. The monitoring team has basic understating to incorporate the effect of economic changes in capital investment decisions.

a175 There is monitoring of the performance of capital investment decisions constantly.

a176. Top management usually takes immediate corrective measures in case of cash flow deviations.

aa27. Debt

financing is easy

in Pakistan

a139,a141

aa28. Debt

financing effect on WACC

a143,a147

aa29. Reliable

and valuable

conditions

A151,a153

aa30. Easy and

risk-sharing

financing

A157,a160

aa31.

Implementation designed and

handling barriers

A16.Implementation aa31, aa32 a151,a153 aa32.

Involvement of

top management in

Implementation a166,a168

aa33. Periodic updates in the monitoring stage a171,a173

A17. Monitoring aa33, aа34
A14. Debt financing aa27, aа28.

A15.Islamic

Financing

aa29, aa30 aa34. Monitoring

and corrections

a175,a176 
INDEPENDENT JOURNAL OF MANAGEMENT \& PRODUCTION (IJM\&P)

http://www.ijmp.jor.br

v. 11, n. 7, November - December 2020

ISSN: 2236-269X

DOI: 10.14807/ijmp.v11i7.1231

a179. Controlling is the core phase in which we cover all discrepancies occurred in CAPEX

a181 Accounting systems are capable enough to facilitate controlling capital investment decision.

a184 Top management understands and helps in case of abrupt changes uncontrollable factors

a187. Finance executives are fully aware of the issues and programs of the project

a191. A post-audit process provides an appropriate feedback mechanism.

A194 The post-audits reports are used as reference and basis for future CAPEX.

a197 Post-Audits highlight the mistakes in current capital investment decision and contribute to improving existing investment opportunities

a201. Post-audit finds are properly documented and reported

\begin{tabular}{|c|c|}
\hline $\begin{array}{l}\text { aa35. Corrective } \\
\text { responsibilities } \\
\text { a179,a181 }\end{array}$ & $\begin{array}{c}\text { A18. Control } \\
\text { аa35, аа36 }\end{array}$ \\
\hline $\begin{array}{c}\text { aa36. Corrective } \\
\text { responsibilities } \\
\text { a184,a187 }\end{array}$ & \\
\hline $\begin{array}{c}\text { aa37. Feedback } \\
\text { and reference } \\
\text { system } \\
\text { a191,a194 }\end{array}$ & \multirow[t]{2}{*}{$\begin{array}{l}\text { A19. Post audit } \\
\text { aa37, aa38 }\end{array}$} \\
\hline $\begin{array}{c}\text { aa38. Response } \\
\text { on mistake and } \\
\text { report } \\
\text { documented } \\
\text { a197,a201 }\end{array}$ & \\
\hline
\end{tabular}

Appendix B: Summary merged initial categories

\begin{tabular}{|c|c|}
\hline Initial categories & Initial meanings \\
\hline Economic analysis & $\begin{array}{l}\text { Economic Situations and The expectation from } \\
\text { Government; Economic conditions supportive for } \\
\text { investment }\end{array}$ \\
\hline Planning & $\begin{array}{l}\text { Planning is the essential phase to start evaluation } \\
\text { CAPEX; Planning has measured the worthiness }\end{array}$ \\
\hline Idea Generation & Investment Idea; Importance of Idea \\
\hline Market analysis & $\begin{array}{l}\text { Market Analysis is the key to evaluate CAPE; Market } \\
\text { potential and market share awareness }\end{array}$ \\
\hline technical Analysis & $\begin{array}{l}\text { Technical updated knowledge; Technical support is } \\
\text { vital for any long term investment }\end{array}$ \\
\hline Financial Analysis & Financial evaluation; Risk and return \\
\hline Technological Analysis & $\begin{array}{l}\text { Technology awareness is compulsory before making } \\
\text { decisions; Technology overcomes future challenges }\end{array}$ \\
\hline Risk Analysis & $\begin{array}{l}\text { Uncertainty of cash flows and returns must measure to } \\
\text { prepare a feasibility report.; Risk is essential as } \\
\text { financial analysis }\end{array}$ \\
\hline Ecological analysis & $\begin{array}{l}\text { Environmental damages and restoration; Public } \\
\text { health }\end{array}$ \\
\hline Risk evaluation & $\begin{array}{l}\text { Quantitatively, Decision tree analysis and Monte } \\
\text { Carlo simulation }\end{array}$ \\
\hline Traditional techniques & $\begin{array}{l}\text { Discounted and non-discounted techniques used to } \\
\text { evaluate the Capex, The Selection phase is the } \\
\text { essential phase of evaluating CAPEX }\end{array}$ \\
\hline Real options & Real options support DCF, Real option methods \\
\hline Equity financing & $\begin{array}{l}\text { Equity financing is the option; IPOs depended upon } \\
\text { the cost of financing }\end{array}$ \\
\hline Debt financing & $\begin{array}{l}\text { Debt financing is easy in Pakistan; Debt financing } \\
\text { effect on WACC }\end{array}$ \\
\hline Islamic assets based Financing & $\begin{array}{l}\text { Reliable and valuable conditions; Easy and risk- } \\
\text { sharing financing }\end{array}$ \\
\hline Implementation & $\begin{array}{l}\text { Implementation designed and handling barriers; } \\
\text { Involvement of top management in Implementation }\end{array}$ \\
\hline Monitoring & $\begin{array}{l}\text { Periodic updates in the monitoring stage; Monitoring } \\
\text { and corrections }\end{array}$ \\
\hline Control & Covered discrepancies; Corrective responsibilities \\
\hline Post audit & $\begin{array}{l}\text { Feedback and reference system; Response on } \\
\text { mistake and report documented }\end{array}$ \\
\hline
\end{tabular}


INDEPENDENT JOURNAL OF MANAGEMENT \& PRODUCTION (IJM\&P)

http://www.ijmp.jor.br

v. 11, n. 7, November - December 2020

ISSN: 2236-269X

DOI: 10.14807/ijmp.v11i7.1231

Appendix C: The main categories form-focused coding

\begin{tabular}{ll}
\hline Focused categories & Initial meanings \\
\hline Idea Generation & Investment Idea; Importance of Idea \\
\hline Planning & Planning is the essential phase to start evaluation \\
& CAPEX; Planning has measured the worthiness \\
\hline Analysis & Economic analysis; Market analysis; Financial \\
& Analysis; Technological Analysis; Risk Analysis; \\
& Ecological analysis \\
\hline Risk evaluation & $\begin{array}{l}\text { Quantitatively, Decision tree analysis and Monte } \\
\text { Carlo simulation }\end{array}$ \\
\hline Selection & Traditional techniques; Real options \\
\hline Mode of financing & Equity financing; Debt financing; Islamic Financing \\
\hline Implementation & Implementation designed and handling barriers; \\
& Involvement of top management in Implementation \\
\hline Monitoring and Control & Periodic updates in the monitoring stage; Monitoring \\
& and corrections; \\
\hline Post audit & Covered discrepancies; Corrective responsibilities \\
\hline & Feedback and reference system; Response on \\
\hline
\end{tabular}

